\title{
PENERAPAN MODEL DIRECT INSTRUCTION PADA PEMBELAJARAN FISIKA
}

\author{
Aantri Heriyanti ${ }^{1}$,Ovilia Putri Utami Gumay ${ }^{2}$, \\ Progam Studi Pendidikan Fisika, STKIP-PGRI Lubuklinggau ${ }^{1,2}$ \\ aantri.heriyanti@yahoo.com ${ }^{1}$ \\ Submit, 25-05-2018 Accepted, 16-06-2018 Publish, 28-12-2018
}

\begin{abstract}
VIII SMP ArRisalah Lubuklinggau academic year 2017/2018 after applied Direct Instruction model. The type of research is quasi-experimental research, with the design used is one group pretest and posttest design. The population in this study is all students of class VIII SMP Ar-Risalah Lubuklinggau academic year 2017/2018. The sample of the study consisted of one class taken at random by drawing the class VIII.B. Technique of data collecting using technique of test. Student test score data were analyzed using t-test. Based on the results of the analysis of the final test data obtained $t$ count $=2.84$ greater than ttable $=$ 1.703 with the average score of the final test of students amounted to 73.89 and the percentage of complete students reached $82.14 \%$. So it can be concluded that the results of physics learning class VIII SMP ArRisalah Lubuklinggau academic year 2017/2018 after the implementation of Direct Instruction model significantly completed.
\end{abstract}

Keywords: Direct Instruction Model, Learning Outcomes, Physics.

Abstrak: penelitian ini bertujuan untuk mengetahui ketuntasan hasil belajar fisika siswa kelas VIII SMP Ar-Risalah Lubuklinggau tahun pelajaran 2017/2018 setelah diterapkan model Direct Instruction. Jenis penelitian adalah penelitian eksperimen semu, dengan desain yang digunakan adalah one group pretest dan postest design. Populasi dalam penelitian ini adalah seluruh siswa kelas VIII SMP Ar-Risalah Lubuklinggau tahun pelajaran 2017/2018. Sampel penelitian terdiri dari satu kelas diambil secara acak dengan cara diundi yaitu kelas VIII.B. Teknik pengumpulan data menggunakan teknik tes. Data nilai tes siswa dianalisis dengan menggunakan uji-t. Berdasarkan hasil analisis data tes akhir didapatkan $t_{\text {hitung }}=$ 2,84 lebih besar dari $t_{\text {tabel }}=1,703$ dengan nilai rata-rata tes akhir siswa sebesar 73,89 dan persentase jumlah siswa yang tuntas mencapai 82,14\%. Sehingga dapat disimpulkan bahwa hasil belajar fisika siswa kelas VIII SMP Ar-Risalah Lubuklinggau tahun pelajaran 2017/2018 setelah penerapan model Direct Instruction signifikan tuntas.

Kata Kunci: Fisika, Hasil Belajar, Model Direct Instruction

\section{PENDAHULUAN}

Pendidikan merupakan aspek yang sangat penting dalam meningkatkan kualitas bangsa. Dengan pendidikan dihasilkan sumber daya manusia yang berwawasan luas, memiliki kreativitas tinggi dan mampu bersaing dengan bangsa lain di era globalisasi.

Menurut Trianto (2010) Pendidikan adalah salah satu bentuk perwujudan kebudayaan manusia yang dinamis dan sarat perkembangan. Oleh karena itu, perubahan atau perkembangan pendidikan adalah hal yang memang seharusnya terjadi sejalan dengan perubahan budaya kehidupan. Perubahan dalam arti perbaikan pendidikan pada semua tingkat perlu terus menerus dilakukan sebagai antisipasi kepentingan masa depan.

Pada hakikatnya pendidikan adalah kegiatan belajar. Sebagai mana yang dikemukakan oleh Komisi Pendidikan Internasional dalam Fathurrohman (2015) sejalan dengan empat pilar pendidikan universal seperti yang di rumuskan UNESCO, yaitu; (1) learning to know, yang berarti juga learning to learn (2) 
learning to do, (3), ) learning to be dan (4) learning live together. Learning to know atau lealning to learn mengandung pengertian bahwa belajar itu pada dasarnya tidak hanya berorientasi kepada produk atau hasil belajar, tetapi juga harus berorientasi kepada proses belajar.

Learning to do mengandung pengertian bahwa belajar itu bukan sekedar mendengar dan melihat dengan tujuan akumulasi pengetahua, melainkan berbuat dengan tujuan akhir penguasaan kompetensi yang sangat diperlukan dalam era persaingan global. learning to be mengandung pengertian bahwa belajar adalah membentuk manusia menjadi dirinya sendiri. Dengan kata lain, belajar untuk mengaktualisasikan dirinya sendiri.

Sebagai individu dengan kepribadian yang memiliki tanggung jawab sebagai manusia. Learning live together adalah belajar untuk bekerja sama. Hal ini sangat diperlukan sesuai dengan tuntutan kebutuhan dalam masyarakat global di mana manusia baik secara individual maupun secara kelompok tidak mungkin dapat hidup sendiri atau mengasingkandiri bersama kelompoknya, (Fathurrohman, 2015).

Salah satu faktor yang berperan dalam kegiatan belajar adalah guru. Menurut Wena (2011) guru sebagai komponen penting dari tenaga kependidikan, yang memiliki tugas untuk melaksanakan proses pembelajaran.

Untuk itu, proses belajar tidak hanya memberikan keleluasaan bagi seorang guru dalam manampilkan gaya mengajarnya namun perlu diperhatikan pula bagaimana peran siswa sesungguhnya dalam proses belajar. Proses belajar yang baik adalah proses belajar yang selalu melibatkan siswa secara aktif dalam setiap kegiatan belajar serta dapat meningkatkan hasil belajarnya.

Berdasarkan observasi di SMP ArRisalah Lubuklinggau pada tanggal 23 Februari 2017 berupa wawancara diperoleh beberapa informasi bahwa hasil belajar siswa pada mata pelajaran fisika belum sesuai dengan yang diharapkan, terlihat dari nilai ulangan harian pada semester I tahun pelajaran 2017/2018 disalah satu kelas VIII yang berjumlah 57 siswa, hanya 25 siswa $(43,86 \%)$ yang mencapai Kriteria Ketuntasan Minimal (KKM) sedangkan 32 siswa $(56,14 \%)$ belum mencapai KKM yang ditetapkan oleh sekolah yaitu 70 dengan rata-rata sebesar 57,53. Hal ini dikarenakan siswa kurang berminat untuk belajar fisika karena mata pelajaran fisika merupakan pelajaran yang cukup sulit.

Oleh karena itu, guru perlu menerapkan model pembelajaran yang tepat agar dapat meningkatkan pengetahuan dan hasil belajar siswa dengan baik. Salah satu model pembelajaran yang digunakan adalah model Direct Instruction.

Menurut Arends (dalam Trianto, 2010) model pembelajaran langsung (Direct Instruction) adalah salah satu pendekatan mengajar yang dirancang khusus untuk menunjang proses belajar siswa yang berkaitan dengan pengetahuan deklaratif dan pengetahuan prosedural yang terstruktur dengan baik, yang dapat diajarkan dengan pola kegiatan yang bertahap, selangkah demi selangkah, terstruktur, mengarahkan kegiatan para siswa, dan mempertahankan fokus pencapaian akademik.

Sedangkan menurut Uno (2011) pembelajaran langsung (DI) adalah 
program yang paling efektif untuk mengukur pencpaian keahlian dasar, keahlian dalam memahami satuan materi dan konsep diri sendiri.

Berdasarkan penjelasan tersebut maka dapat dipahami bahwa model Direct Instruction adalah suatu pendekatan atau teknik pemindahan pengetahuan dari guru yang dapat dilakukan secara bertahap dan mempertahankan pencapaian akademik atau hasil belajar siswa.

\section{LANDASAN TEORI}

Bloom (dalam Suprijono, 2009) bahwa "hasil belajar mencakup kemampuan kognitif. Hasil belajar kognitif meliputi knowledge (pengetahuan ingatan), comprehension (pemahaman, menjelaskan meringkas, contoh), application (menerapkan), analysis (menguraikan, menentukan hubungan), synthesis (mengorganisasikan, merencanakan, membentuk bangunan baru), dan evaluation (menilai).

Menurut Trianto (2010) model pengajaran langsung merupakan salah satu model pembelajaran yang di rancang khusus untuk menunjang proses belajar siswa yang berkaitan dengan pengetahuan deklaratif dan pengetahuan prosedural yang terstruktur dengan baik yang dapat diajarkan dengan pola kegiatan yang bertahap, serta selangkah demi selangkah. Fathurrohman (2015) mengatakan pembelajaran adalah usaha sadar dari guru untuk membuat peserta didik belajar, yaitu terjadinya perubahan tingkah laku pada diri siswa yang belajar.

\section{METODE PENELITIAN}

Dalam penelitian ini menggunakan metode eksperimen semu (quasi eksperiment) yang dilaksanakan pada satu sampel. Nazir (2009) mengatakan metode eksperimen semu merupakan penelitian yang mendekati percobaan sungguhan di mana tidak mungkin mengadakan control /memanipulasikan semua variabel yang relevan.

Desain penelitian dalam penelitian ini adalah one group pretest dan postest design. Desain penelitian ini dapat dilihat pada tabel 2.

Tabel 1. Desain Penelitian

\begin{tabular}{ccc}
\hline Pre-test & Treatment & Post-test \\
\hline $\mathrm{O}_{1}$ & $\mathrm{X}$ & $\mathrm{O}_{2}$
\end{tabular}

Sumber : Sugiyono (2006)

Keterangan:

$\mathrm{O}_{1}=$ Nilai tes awal

$\mathrm{O}_{2}=$ Nilai tes akhir

$\mathrm{X}=$ Treatment (model pembelajaran Direct Instruction)

Variabel pada penelitian ini terdiri atas: (1) variabel bebas adalah pembelajaran langsung, dan (2) variabel terikat adalah hasil belajar siswa. Penelitian ini diadakan di SMP ArRisalah Lubuklingau, yang berlangsung pada semester genap tahun ajaran 2017/2018. Populasi dalam penelitian ini adalah seluruh siswa kelas VIII SMP ArRisalah Lubuklinggau tahun ajaran 2017/2018 yang berjumlah 2 kelas.

Sampel penelitian ini adalah seluruh siswa kelas VIII B SMP Ar-Risalah yang berjumlah 28 siswa. Sampel ini ditentukan dengan teknik Simple Random Sampling. Teknik pengumpulan data pada penelitian ini adalah instrumen tes, berupa soal essay sebanyak enam soal.

Dalam penelitian ini, analisis data yang dilakukan terhadap data hasil belajar siswa sebagai berikut :

1. Mencari nilai rata-rata dan simpangan baku. Mencari nilai rata-rata dan simpangan baku pada tes awal dan tes akhir menggunakan rumus:

$$
\bar{x}=\frac{\sum x_{i}}{n}
$$

Sudjana, 2005 
$s=\sqrt{\frac{\sum\left(x_{i}-\bar{x}\right)^{2}}{n-1}}$

Keterangan: (Sugiyono, 2006)

$s$ = simpangan baku

$x_{i}=$ nilai siswa keseluruhan

$\bar{x}=$ nilai rata-rata sampel

$n$ = banyaknya siswa dalam sampel

2. Uji normalitas. Uji normalitas bertujuan untuk melihat apakah kedua kelompok data, populasi berdistribusi normal atau tidak. Perhitungan uji normalitas distribusi ini menggunakan rumus Chi-kuadrat sebagai berikut:

$\chi^{2}=\sum \frac{\left(f_{0}-f_{h}\right)^{2}}{f_{h}}$

(Sugiyono, 2006)

Keterangan:

$\chi^{2}=$ chi-kuadrat yang dicari

$f_{0}=$ frekuensi dari hasil pengamatan

$f_{h}=$ frekuensi yang diharapkan

Selanjutnya $\quad \chi^{2}$ hitung dibandingkan terhadap $\chi_{\text {tabel }}^{2}$ dengan derajat kebebasan $(\mathrm{dk})=\mathrm{k}-1$, dimana $\mathrm{k}$ adalah banyaknya kelas interval. Jika $\chi_{\text {hitung }}^{2}<\chi_{\text {tabel }}^{2}$, maka data tersebut terdistribusi normal, dan jika $\chi_{\text {hitung }}^{2} \geq$ $\chi_{\text {tabel }}^{2}$ maka data tidak terdistribusi normal.

3. Uji Hipotesis. Karena simpangan baku populasi tidak diketahui dan data berdistribusi normal, maka untuk menguji hipotesis menggunakan t-tes satu sampel dengan rumus dibawah ini:

$t=\frac{\bar{x}-\mu_{0}}{\frac{s}{\sqrt{n}}}$

(Sugiyono, 2006)
Keterangan:

$t=$ nilai $t$ yang dihitung

$\bar{x}=$ nilai rata-rata

$\mu_{0}=$ nilai yang dihipotesis

$s$ = simpangan baku sampel

$n=$ jumlah anggota sampel

Kriteria pengujiannya adalah Jika $\mathrm{t}_{\text {hitung }} \leq \mathrm{t}_{\text {tabel }}$ maka $\mathrm{H}_{0}$ diterima dan $\mathrm{H}_{\mathrm{a}}$ ditolak. Sebaliknya jika $t_{\text {hitung }}>t_{\text {tabel }}$ maka $\mathrm{H}_{0}$ ditolak dan $\mathrm{H}_{\mathrm{a}}$ diterima. Dimana $\mathrm{t}_{\text {tabel }}$ didapatkan dari daftar distribusi t dengan ( $\alpha=0,05), \mathrm{dk}=\mathrm{n}-1$.

\section{HASIL DAN PEMBAHASAN}

Tabel 2 Hasil Penelitian

\begin{tabular}{|c|c|c|c|}
\hline \multirow[t]{2}{*}{ No. } & \multirow[t]{2}{*}{ Statistik } & \multicolumn{2}{|c|}{ Nilai } \\
\hline & & $\overline{\text { Pre-test }}$ & Post-test \\
\hline 1. & $\begin{array}{l}\text { Ukuran } \\
\text { sampel }\end{array}$ & 28 & 28 \\
\hline 2. & rata-rata & 25,71 & 73,89 \\
\hline 3. & $\begin{array}{l}\text { Simpangan } \\
\text { baku }\end{array}$ & 8,82 & 7,24 \\
\hline 4. & $\begin{array}{l}\text { Nilai } \\
\text { maksimum }\end{array}$ & 43 & 86 \\
\hline 5. & $\begin{array}{l}\text { Nilai } \\
\text { minimum }\end{array}$ & 8 & 59 \\
\hline 6. & $\begin{array}{l}\text { Siswa yang } \\
\text { tuntas }\end{array}$ & $\begin{array}{c}0 \text { siswa } \\
(0 \%)\end{array}$ & $\begin{array}{c}23 \text { siswa } \\
(82,14 \%)\end{array}$ \\
\hline 7. & $\begin{array}{l}\text { Siswa yang } \\
\text { tidak tuntas }\end{array}$ & $\begin{array}{c}28 \text { siswa } \\
(100 \%)\end{array}$ & $\begin{array}{c}5 \text { siswa } \\
(17,86 \%)\end{array}$ \\
\hline
\end{tabular}

Tabel di atas menunjukan bahwa nilai rata-rata pre-test siswa adalah 25,71 dan nilai rata-rata post-test adalah 73,89 . Hal ini menujukan bahwa telah terjadi peningkatan hasil belajar setelah diterapkan model Direct Instruction (DI) yaitu sebesar 48,14 poin.. Nilai rata-rata post-test sebesar 73,89 telah memenuhi nilai kreteria ketuntasan minimal (KKM) mata pelajaran IPA di SMP Ar-Risalah Lubuklinggau.

Untuk menarik kesimpulan dari data tes akhir, maka dilakukan pengujian hipotesis secara statistik, Namun sebelum pengujian dilakukan terlebih dahulu dilakukan uji normalitas.

Uji normalitas bertujuan untuk melihat apakah data hasil tes siswa 
terdistribusi normal atau tidak. Berdasarkan ketentuan perhitungan statistik mengenai uji normalitas dengan taraf kepercayaan $\alpha=0,05$, jika $\chi_{\text {hitung }}^{2}<$

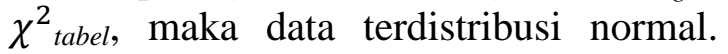
Kemudian jika $\chi_{\text {hitung }}^{2}>\chi_{\text {tabel, maka }}^{2}$ data terdistribusi tidak normal. Hasil uji normalitas data hasil belajar siswa dapat dilihat pada tebel 4 .

Tabel 3. Hasil Uji Normalitas

\begin{tabular}{ccccc}
\hline Data & $\chi^{2}{ }_{\text {hitung }}$ & Dk & $\chi^{2}$ tabel & $\begin{array}{c}\text { Kesimpu } \\
\text { lan }\end{array}$ \\
\hline Normalitas & 4,7413 & 5 & 11,070 & Normal \\
\hline
\end{tabular}

Berdasarkan Tabel 4 menunjukkan nilai uji $\chi^{2}{ }_{\text {hitung }}$ data hasil belajar siswa lebih kecil daripada $\chi^{2}$ tabel sehingga dapat disimpulkan bahwa data tersebut berdistribusi normal, maka untuk menguji hipotesis menggunakan uji $\mathrm{t}$ dengan taraf kepercayaan $\alpha=0,05$, jika $t_{\text {hitung }}>t_{\text {tabel }}$, hal ini berarti $\mathrm{H}_{0}$ ditolak dan $\mathrm{H}_{\mathrm{a}}$ diterima. Hasil uji-t data pre-test dan post-test dapat dilihat pada Tabel 5.

Tabel 4. Hasil Uji Hipotesis

\begin{tabular}{ccccc}
\hline Data & $\mathrm{t}_{\text {hitun }}$ & $\mathrm{dk}(\mathrm{n}-$ & $t_{\text {tabel }}$ & Keterangan \\
& \multicolumn{1}{c}{$1)$} & & \\
\hline Uji-t & 2,84 & 27 & 1,703 & $\begin{array}{c}\text { Ha diterima, } \mathrm{H}_{0} \\
\text { ditolak }\end{array}$ \\
\hline
\end{tabular}

Berdasarkan Tabel 5 dapat dilihat bahwa hasil uji-t post-test menunjukkan nilai $t_{\text {hitung }}(2,84)>t_{\text {tabel }}(1,703)$, hal ini berarti $\mathrm{H}_{0}$ ditolak dan $\mathrm{H}_{\mathrm{a}}$ diterima artinya hasil belajar siswa setelah mengikuti pembelajaran fisika dengan menggunakan model Direct Instruction lebih dari sama dengan 70.

Berdasarkan uraian tersebut dapat dilihat gambaran data lebih jelas, diketahui nilai rata-rata untuk pre-test sebesar 25,71 dan nilai rata-rata untuk post-test yaitu 73,89 . Artinya terdapat peningkatan rata-rata sebesar 48,18 setelah diterapkan model pembelajaran direct instruction pada materi energi di SMP Ar-Risalah Lubuklinggau. Secara rinci peningkatan hasil belajar ini dapat dilihat pada Gambar 1.

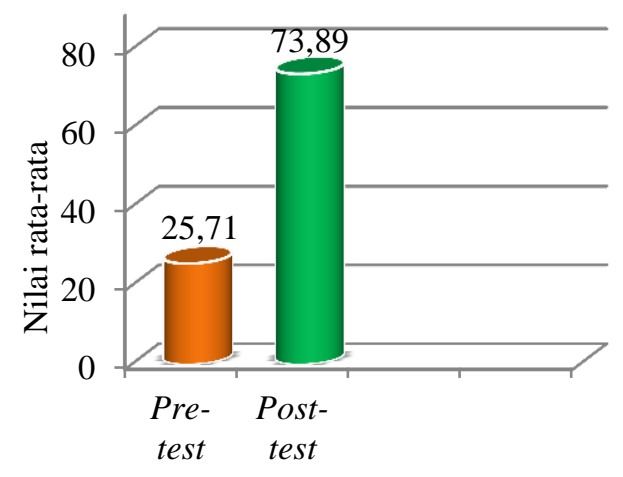

Grafik 1. Nilai Rata-rata Pre-test dan Post-test

Berdasarkan Gambar 1 dapat disimpulkan bahwa hasil belajar fisika siswa kelas VIII SMP Ar-Risalah Lubuklinggau tahun pelajaran 2017/2018 setelah penerapan model Direct Instruction signifikan tuntas.

Berdasarkan hasil penelitian yang dilakukan (tabel 3), dapat kita lihat perbedaan nilai siswa secara signifikan antara nilai pre-test dan nilai post-test. Hal ini membuktikan bahwa ada peningkatan nilai siswa setelah diterapkan model pembelajaran langsung pada materi energi dan usaha di SMP Ar-Risalah Lubuklinggau

Pada pembelajaran pertama menggunakan model Direct Instruction. Pada pertemuan ini dari 28 siswa yang hadir hanya ada 11 siswa yang dapat menyelesaikannya dengan baik sedangkan yang lainnya masih belum memahami materi.

siswa terlihat kondusif dan memperhatikan guru dalam menjelaskan materi. Dari 28 siswa yang hadir ada 19 siswa yang dapat mengikuti pembelajaran dengan baik. Hal ini dikarenakan siswa sudah mulai terbiasa dalam mengikuti model Direct Instruction.

Pada pertemuan ketiga semua siswa lebih aktif dalam memahami materi. Pada pertemuan ini hambatan-hambatan tidak 
terjadi lagi karena siswa sudah mengerti dan menyenangi kegiatan pembelajaran yang dilakukan. Dari 28 siswa yang mengikuti pembelajaran semuanya dapat memahami dan mengikuti pembelajaran dengan baik.

Setelah kegiatan pembelajaran maka dilakukan post-test yang hasil perhitungan post-test didapatkan nilai rata-rata hasil post-test adalah 73,89 , nilai terendahnya adalah 59, nilai tertingginya adalah 86 serta simpangan bakunya adalah 7,24. Ini berarti bahwa terdapat peningkatan hasil belajar antara nilai rata-rata pre-test dan post-test sebesar 48,18. Dan hasil uji-t post-test menunjukkan bahwa $\mathrm{t}_{\text {hitung }}$ $(2,84)>t_{\text {tabel }}(1,703)$, hal ini berarti $\mathrm{H}_{0}$ ditolak dan $\mathrm{H}_{\mathrm{a}}$ diterima artinya hasil belajar siswa setelah mengikuti pembelajaran fisika dengan menggunakan model Direct Instruction lebih dari sama dengan 70.

\section{SIMPULAN}

Berdasarkan hasil analisis data penelitian menunjukkan hasil uji-t post-test bahwa $\mathrm{t}_{\text {hitung }}=2,84$ lebih besar dari $\mathrm{t}_{\text {tabel }}=1,703$ dengan nilai rata-rata tes akhir siswa sebesar 73,89 dan persentase jumlah siswa yang tuntas mencapai $82,14 \%$. Sehingga dapat disimpulkan bahwa hasil belajar fisika siswa kelas VIII SMP Ar-Risalah Lubuklinggau tahun pelajaran 2017/2018 setelah penerapan model Direct Instruction signifikan tuntas.

\section{DAFTAR PUSTAKA}

Fathurrohman, M. (2015). Model-model Pembelajaran Inovatif. Yogyakarta: Ar-Ruzz Media.

Nazir, Moh. (2009). Metode Penelitian. Jakarta: Ghalia Indonesia

Sudjana, Nana. (2005). Metoda Statistika. Bandung: Tarsito

Sugiyono. (2006). Metode Penelitian Administrasi. Bandung: Alpabeta.

Suprijono, A. (2009).Cooperatif Learning. Yogyakarta: Pustaka Belajar.

Trianto. (2010). Mendesain Model Pembelajaran Inovatif-Progresif. Jakarta: Prenada Media.

Uno B, Hamzah. (2011). Perencanaan pembelajaran. Jakarta: Bumi Aksara

Wena, Made. (2011). Strategi Pembelajaran Inovatif Kontemporer. Jakarta: Bumi Aksara. 